\title{
Corrigendum: Data practices and inequality in South African early childhood development policy: Technocratic management versus social transformation
}

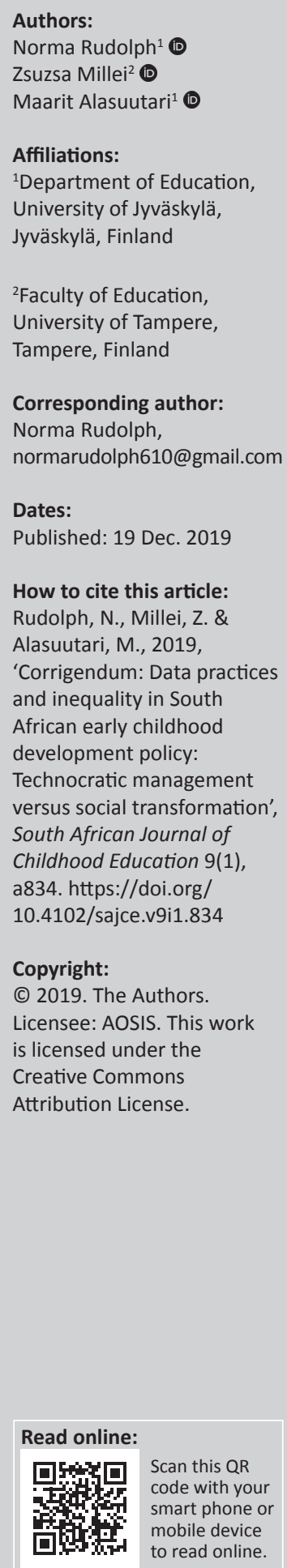

In the version of this article published earlier, the name of the second author, Zsuzsa Millei, was inadvertently misspelt as 'Zsuzsanna Millei'. The second author's name should have appeared as 'Zsuzsa Millei' throughout the author list and 'How to cite' information section. This correction does not alter the study's findings of significance or overall interpretation of the study results. 


\section{Data practices and inequality in South African early childhood development policy: Technocratic management versus social transformation}

\begin{tabular}{|c|c|}
\hline \multicolumn{2}{|c|}{$\begin{array}{l}\text { Authors: } \\
\text { Norma Rudolph } \\
\text { Zsuzsanna Millei }^{1} \\
\text { Maarit Alasuutari }\end{array}$} \\
\hline \multicolumn{2}{|c|}{$\begin{array}{l}\text { Affiliations: } \\
{ }^{1} \text { Department of Education, } \\
\text { University of Jyväskylä, } \\
\text { Jyväskylä, Finland }\end{array}$} \\
\hline \multicolumn{2}{|c|}{$\begin{array}{l}{ }^{2} \text { Faculty of Education, } \\
\text { University of Tampere, } \\
\text { Tampere, Finland }\end{array}$} \\
\hline \multicolumn{2}{|c|}{$\begin{array}{l}\text { Corresponding author: } \\
\text { Norma Rudolph, } \\
\text { normarudolph610@gmail.com }\end{array}$} \\
\hline \multicolumn{2}{|c|}{$\begin{array}{l}\text { Received: } 21 \text { Mar. } 2019 \\
\text { Accepted: } 14 \text { June } 2019 \\
\text { Published: } 17 \text { Oct. } 2019\end{array}$} \\
\hline \multicolumn{2}{|c|}{$\begin{array}{l}\text { How to cite this article: } \\
\text { Rudolph, N., Millei, Z. \& } \\
\text { Alasuutari, M., 2019, 'Data } \\
\text { practices and inequality in } \\
\text { South African early childhood } \\
\text { development policy: } \\
\text { Technocratic management } \\
\text { versus social transformation', } \\
\text { South African Journal of } \\
\text { Childhood Education 9(1), } \\
\text { a756. https://doi.org/ } \\
\text { 10.4102/sajce.v9i1.756 }\end{array}$} \\
\hline \multicolumn{2}{|c|}{$\begin{array}{l}\text { Copyright: } \\
\text { (c) 2019. The Authors } \\
\text { Licensee: AOSIS. This } \\
\text { is licensed under the } \\
\text { Creative Commons } \\
\text { Attribution License. }\end{array}$} \\
\hline \multicolumn{2}{|l|}{ Read online: } \\
\hline 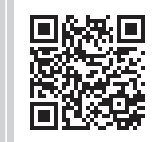 & $\begin{array}{l}\text { Scan this QR } \\
\text { code with your } \\
\text { smart phone or } \\
\text { mobile device } \\
\text { to read online. }\end{array}$ \\
\hline
\end{tabular}

Background: In 1994, the African National Congress identified early childhood development as a potential strategy to redress the inequalities of apartheid, however, two and a half decades later, poverty still persists, and South Africa is one of the most unequal countries in the world.

Aim: This article explores how policy texts based on and with the use of certain data practices establish 'truths' about childhoods and society, construct families and communities, and determine forms of provision to address inequality.

Setting: In 2015, the South African government published the National Integrated Early Childhood Policy (NIECDP) to continue to address poverty and inequality. Its implementation increasingly draws on data practices that measure and inform solutions. The use of data practices, while also providing needed information, prioritises solutions that proceed in technocratic ways instead of facilitating social change.

Methods: With a critical discourse analysis of policy texts and the introduction of alternatives, the analysis seeks to highlight the power and knowledge hierarchies that construct the policies of NIECDP.

Results: This article demonstrates how discourses and data practices prioritise 'the government of poverty' instead of helping to eliminate it and silence the voices of those living with poverty. This form of government through data also undermines the policy's potential to respond to the different life chances resulting from the diverse conditions in which young children live in South Africa.

Conclusion: This article seeks to re-open a debate that the NIECDP successfully silenced, specifically who benefits, who speaks and who is silenced.

Keywords: data practices; policy analysis; South Africa; early childhood; social justice.

\section{Global discourses with a propensity for measurement}

There is a global agreement on the benefits of early childhood education, including poverty alleviation, and a growing consensus around mobilising resources for early childhood services based on needs established on data (Britto et al. 2018). However, the way 'data' and 'evidence' are constructed and the kind of data practices that are used warrants closer attention. While centralised population-based data are necessary for general planning, allocation of resources and identifying areas needing policy input, exclusive reliance on this kind of data-driven policy and decisionmaking can risk depoliticising early childhood policy (Dahlberg \& Moss 2005; Morabito, Vandenbroeck \& Roose 2013) and silencing broad, continuous and necessary debates about early childhood services. More specifically, it leaves little space for discussions regarding notions and values underpinning early childhood provision, such as the competing understandings of childhood and society promoted by diverse communities, and the values, which inform funding strategies. While challenges to the global consensus and policy decisions involving data use can be found in the literature (Campbell-Barr, Lavelle \& Wickett 2012; Cannella, Pèrez \& Lee 2016; Dahlberg, Moss \& Pence 1999; Millei \& Gallagher 2017; Penn 2010; Roberts-Holmes 2015), there is little critical attention being given to this issue in South Africa. The acclaim for the long-awaited integrated early childhood services and increased government funding promised in the South African 2015 National Integrated Early Childhood Development Policy (NIECDP) (RSA 2015) has overshadowed critical response to the specific policy choices and programme options that are defined and delivered on particular presentations of data. By relying solely on centralised planning, the NIECDP constrains space for beneficiaries to contribute more refined data generated 
through decentralised participatory processes at the local level to guide a responsive integrated approach.

In this article, we analyse the kinds of data practices promoted in the 2015 South African NIECDP and argue that the current dominant global discourses, with a propensity for measurement and a particular kind of data use, undermine the stated policy intention to address poverty and inequality. By revealing the underlying policy discourses and power relations that shape the collection, administration and use of data, we aim to stimulate debate about different data practices and constructions of evidence in current early childhood policy in South Africa.

\section{Systematic data practices and the analysis of policies}

The stated intention of the 2015 NIECPD is to address inequality, claiming that inequality within and between populations has its origins in poor early childhood experiences' (RSA 2015). Consequently, it argues that investment in early childhood development (ECD) that targets the underlying social and economic causes and consequences of risk factors can 'limit inequality at its source' (RSA 2015). To create information on how and what kind of investments are to be taken, an evidence-based policymaking discourse is mobilised. This calls for the collection of data based on an autocratic and bureaucratic point of view. The problem is, however, that instead of gathering local data in discussions with community stakeholders, policymakers exclusively use large population data sets and centrally devised measures in determining the set of early childhood services to be funded and scaled up. As a result, there is insufficient detail about local conditions. This kind of standard data practice is explored in the literature as datafication, data-driven and evidence-based decisionmaking. We follow Kelly and Noonan's (2017) distinction between 'systematic practices' and 'edifying practices' of datafication in their research on the Indian public health sector. Bringing Rorty's (1979) notion of 'edifying practices' to their conceptualisation, they emphasise the 'shifts from representing the world (with a view to domesticating it) to cultivating the skills to experience it more fully' (Kelly \& Noonan 2017:878). They oppose standard systematic data practices that represent the world with a view of objectifying and simplifying it to fit normalised understandings. For example, in relation to the measurement of poverty with some numerical indicators, data enact relational object positions, such as positioning some people 'below the poverty line', or in groups that are at 'risk of poverty', thus creating distinctive forms of sociality that are understood in well-rehearsed or normative ways. Kelly and Noonan (2017) remind us that practices are performative and they therefore conceive of data not as a noun or a thing but as a kind of 'doing' that can produce worlds and also reveal new worlds and possibilities through conversation with various stakeholders. Using a practice theoretical approach, they suggest understanding data as being performed within social practices. They promote what they term as 'edifying data practices' that generate mutual exploration and learning of complex conditions through conversation (Kelly \& Noonan 2017).

The standard systematic data practices in the South African early childhood policy scene are used to measure the success of implementation. The South African Early Learning Outcomes Measure (ELOM) seeks to determine the level of success of services, based on the measurement of children's performance improvement (Dawes et al. 2016; DGM Moderator 2016; Snelling et al. 2019). This is in line with the recently launched global campaign by the Early Childhood Action Network $\left(E_{C D A N}{ }^{1}\right)$ that proposes standardising global reporting of implementation based on predetermined 'evidence to inform effectiveness, quality, and scale' (Britto et al. 2018). In addition to its compliance with the global expectation of comparable measurement tools, South African early childhood policy and practice is strongly informed by the dominant position that there is sufficient evidence of effective programmes that should merely be taken to scale (Britto et al. 2018). Thus, it seems that the South African government strategy to reduce inequality is primarily based on needing effective large-scale data sets to determine needs, administer the correct measures of funding and upscaling, and prove success with the measurement of learning outcomes through predefined measurement procedures.

Policymaking, informed and evaluated primarily by quantified measurements, contributes to the process of what Grek and Ozga (2010) term the 'scientisation' of education governance, where it is 'increasingly assumed that it is only knowledge based on data (and in particular statistical knowledge) that can reveal problems and shape solutions' (Grek \& Ozga 2010). Adding to this observation, Dahlberg (2016) notes, in relation to the context of the Global North, that data use follows dominant economic rationalities and neoliberal ideologies. For example, systematic quality assurance and quality control practices use predefined measurement procedures to assess children in terms of predetermined outcomes and, in so doing, govern and normalise young children and their families. In contrast to this approach, she presents an 'ethico-aesthetic paradigm' that accommodates the possibility of imagining and enacting alternatives and thus allowing for change, creativity and hope (Dahlberg 2016).

Dahlberg's (2016) argument is further complicated in South Africa by the colonial history that vests colonial power relations in policy for young children (Porteus 2004). To consider this complex historical and policy terrain, we chose the policy-as-discourse analysis method (Bacchi 2000; Shore \& Wright 2011) to reveal colonial power relations and political agendas inherent in policy texts and processes. This approach highlights the ways in which a 'problem' is represented in policy and how that can frequently generate rather than solve problems. From decolonial perspectives (Mignolo 2007; Santos 2007), policy-as-discourse works towards identifying 1.UNICEF and the World Bank Group launched the Early Childhood Development Action Network (ECDAN) in 2016 see https://www.ecdan.org/. 
hierarchies of knowledge and the ways global colonial and the so-called 'western' perspectives can subjugate or silence other knowledges.

In our analysis, we focus on how policies construct the problem by, firstly, identifying particular policy statements that allude to a problem by using Kendall and Wickham's (1999) method of discourse analysis. We explore the possible meanings implied in a given statement, including the categorisations and binaries it constructs, the way it positions certain people, how it creates and shapes personal and institutional relationships, and draws on stereotypes, notions of equality, justice and injustice, and politics. We scrutinise how different actors, such as children, communities and experts, are constructed and how power relations and hierarchies are produced through these statements. We explore how discourses and described practices align with or subjugate particular understandings of childhood and early childhood education. We relate this to other discourses, concepts and frames mobilising available and dominant discourses, such as global consensus on the benefits of early childhood education and care and systematic data practices.

The policy-as-discourse approach takes the position that policy is a complex, interactive, multi-layered and valueladen process (Shore \& Wright 2011). Therefore, relevant policy documents in their context, as well as those that informed the policy and those that have emerged from it, are analysed in order to create a complex account. We pay particular attention to the 12 background papers produced as part of the diagnostic ECD review that informed the policy (Richter et al. 2012) and the overarching national guiding framework (National Planning Commission 2012; RSA 2011). The reports and literature that have been brought together by the ECDAN to support its recently launched global campaign give us some indication about the kind of dominant early childhood discourses used in South African early childhood policymaking (Britto et al. 2017, 2018). In order to retrace historical contextual information, the analysis is also informed, in addition to the published literature, by the personal archives of one of the authors, including personally stored government reports and personal communications dating back to the 1980 s.

In this study, all of the recent data and most of the historical data are in the public domain and consist of documents that are either already available or in the process of being made available in digital form. Therefore, there are no ethical considerations relating to the source or accessing of data, other than possibly personal communications, which are only used to inform the policy analysis and thus identities are not revealed. In writing up this analysis, we kept asking the questions: what can we say, with what authority and with what consequences? While policy critique focuses on documents, it is still about the people who stood behind those policies. Therefore, analysis and critique must be levelled with knowledge and consideration of the consequences for not only those who were behind these policies but also for those who are reading our analysis.
These ethical considerations guided our decisions, including where to publish this article.

\section{Context for a more 'edifying' policy}

In 1994, when the African National Congress (ANC) came to power in South Africa, it promised to redress the inequalities inherited from the apartheid regime by attacking poverty and deprivation as its first priority. The ANC identified ECD as one strategy for achieving the kind of convivial society envisaged by the 1955 Freedom Charter that had inspired and directed the political and armed struggle that ended apartheid and led to the first democratic election. While there is no longer legal racial discrimination, the spatial inequalities, the human immunodeficiency virus (HIV) pandemic, the poor state of the economy and high unemployment rates have exacerbated poverty and inequality. The most serious consequence of poverty is child hunger, stunting, undernutrition and low birth weight. According to the South African Early Childhood Review 2017, ‘30\% of young children fall below the food poverty line (FPL)' (Hall et al. 2017:8). Nearly one-third of South Africa's children do not have sufficient nutritious food.

The Population Registration Act of 1950 classified people according to their racial characteristics and each group lived in a different area as part of the system of apartheid. Segregation, land dispossession, the system of migrant labour and forced removals dislocated families and communities. The vast majority of indigenous peoples were dispossessed of their ancestral and agricultural lands onto the 'Bantustans' where they eked out a living supported by remittances from family members who worked in cities or on the mines. The political struggle for democracy itself left an indelible mark. Economic policies post-1994 have also deepened inequality (Du Toit 2012).

In the case of schooling, the legacy of apartheid has been exacerbated by the school fee policy. The ANC legislated for free basic public schooling and committed to paying for a standard number of teachers for all schools. However, by allowing school governing bodies to determine fees for additional costs, the schools in previously advantaged areas were able to offer much better schooling at a higher cost to those who could afford to pay. Only a small minority of the previously disenfranchised population had the financial means to relocate to the previously advantaged racially segregated areas, and consequently today enjoy better services. In addition, there are families who have the resources to transport their children to schools in wealthier neighbourhoods. However, the vast majority remain in rural areas or have moved to informal urban areas, which lack services and adequate schooling (Goldberg 2009).

Extensive literature (Christie 2010; Soudien 2004; Unterhalter 2009) portrays the inequitable education provision and curriculum that undermine the intended values of a convivial society post-apartheid. Spreen, Vally and Thapilyal (2012) describe social injustice in education policy in terms of power 
relations in decision-making, pointing to the kind of knowledge that is valued, the legitimacy of actors and the 'ideological acceptance of the broad framework of the globally dominant, neoliberal, political and economic orthodoxy' that undermined equality and equity (Spreen et al. 2012:53). The displacement of the voice and power of beneficiaries by technical experts (Du Toit 2012; Vandenbroeck, Coussée \& Bradt 2010) is evident across the South African education system from the early childhood sector to higher education.

\section{The South African early childhood landscape}

Before the first democratic election in 1994, the system of provision for young children was extremely unequal, with well-funded government preschools in the 'white' education system and reliance by the majority of 'black' children on limited community-based and fee-paying educare centres for children from three to six years. Teachers in preschools were university trained and a relatively small group of nongovernment training organisations offered non-formal training in the 'educare' sector, which fell outside of government influence and dominant apartheid Christian National Education with its fundamental pedagogic approach. This allowed a few non-government organisations to develop innovative and progressive approaches, such as using a Freirian conscientisation approach and drawing on indigenous childcare practices (Biersteker 2018; Swart 1996). Community-based centres with children from three to six years and home visiting programmes located services close to where children lived, encouraging family and community participation (Rudolph 2017). In 1980, the apartheid government introduced a 'school readiness' bridging period to address the high failure and drop-out rate among children classified as 'black'. The non-government 'educare' sector argued instead that schools should be 'ready' to 'receive' and support children and accommodate diversity (ELRU 1994).

For nearly 20 years the primary focus of government services for young children has remained on the introduction and expanding of a single year of provision for children before they enter primary school, referred to as Grade R. This is despite the intended broad integrated approaches set out in the Interim Policy for ECD (DoE 1996) and later in the National Integrated Plan (NIP) (DoE, DOH \& DSD 2005) and the Children's Act (DSD 2005). Grade R is not yet available to all children and those living in urban areas and those with greater financial resources are more likely to be in a Grade $R$ class (Biersteker 2018). Since those classes attached to schools are better funded, educated practitioners prefer to be employed in schools. Drawing on recent research, Biersteker (2018) concludes that 'while Grade R was established as a means of reducing inequalities, it simply extended the advantage to children in more affluent schools' (Biersteker 2018:305).

Before the introduction of and dominant focus on Grade R, the standard model of early childhood provision was in community-based centres with children from three to six years. This format encouraged family and community participation and nurtured peer teaching and learning more closely aligned to traditional childcare arrangements (Rudolph 2017). The community-based system of provision has been eroded by age segregation and the flight of practitioners to better paying jobs in schools (Biersteker 2018), thus undermining the pre-1994 progressive work of non-governmental organisations and reproducing inequality on economic lines.

\section{Constructing 'vulnerable' children and families as the problem}

The NIECDP draws extensively on dominant early childhood discourses that promote ECD as a panacea for all social problems, especially poverty and inequality. This is evident in the exclusive reference in the policy to the 'neuroscience' perspective and human capital. The NIECDP claims that 'inequality between and within populations has its origins in poor early childhood development experiences' (RSA 2015:21). It states that:

The science is conclusive: investments in early childhood development yield lifetime development returns for the child, his or her family and society. Notably, early childhood development has the potential to contribute significantly to the reduction of key development challenges facing South Africa in 2015 , particularly poverty and inequality. (p. 21)

The policy states that it has taken into account 'recent scientific evidence', including the evidence of the 'challenges that young children and families experience, especially those most vulnerable' (RSA 2015:120). 'Vulnerable children' are constituted as:

Those who experience compromised caregiving and/or compromised access to quality early childhood development services because of one or more structural, social, economic, geographic, physical, mental, psychosocial, racial, familial or any other risk factors associated with poor access to services, and/or poor early childhood outcomes. (p. 14)

The primary focus, in the discourse, on 'compromised' caregiving and lack of access to ECD subjugates real conditions of families. By making this discursive move, it is possible to narrow the focus, in line with human capital discourses, to only focus on education. The policy lists 12 of these risk factors, starting with 'Children living in poverty'; and including (RSA 2015):

Orphaned children and other children living without their biological parents; Children living in child-headed households; Children whose caregivers abuse substances such as alcohol and drugs; Children who are exposed to violence; Children living in under-serviced rural areas or urban informal settlements. (p. 14)

Referring again to the Centre on the Developing Child (2007), the policy states that 'Poverty is widely recognised as a root cause of poor child development' and that 'low socioeconomic status is a key predictor of poor early childhood development' (RSA 2015:19). Demarcating, identifying and characterising large groups of children this way makes it possible to amass 
them, collate data about them through systematic data production and make them the specific targets of these policies. Amassing unifies specific conditions, subjugating their real-life conditions to the overarching discourse of needing education. Having shaped the problem in a specific way determines the solution. Consequently, in this case, the solution to the absence of learning is addressed through improving learning outcomes. This kind of construction of the problem denies the many interlinked conditions children experience as discussed above.

A discourse in the UNICEF 2012 report resonates with the NIECDP's construction of poverty:

Leaving a young child alone or in the care of another child is a dereliction of caregiving responsibilities and can have harmful consequences. It exposes the child to increased risk of not only injury, but also abuse and neglect. (pp. 9-10)

Children living without biological parents are described in the NIECDP as being 'especially at risk of being denied the care necessary for their physical and psychosocial well-being' (RSA 2015:14 referring to UNICEF 2012). This perspective disregards the strong argument made in the wake of the AIDS pandemic, that there is a mismatch between international policy definitions and local or community constructions of 'childhood', 'vulnerability' and 'orphanhood'. For example, Meintjes and Giese (2006:407) argued that these global perspectives were 'shifting the terrain of orphanhood at a local level in South Africa and producing new struggles on the ground'. They argued that the construction of 'orphans' in the AIDS pandemic discourses obscures the range of childhood vulnerabilities, especially children living in poverty. Emerging from this literature, a research project facilitating community-based dialogue revealed that the status of children is not static and that children continually move in both directions on a continuum between well-being and vulnerability depending on their changing family circumstances (Rudolph et al. 2008). This research offers a more complex and relational view of poverty, which highlights its temporality. Dialogue in communities, as the above research powerfully shows, can help in revealing the unproductive policy frames that place certain people in static economic categories, as does the NIECDP, rather than relating it to changing socio-political, health, economic conditions and personal circumstances.

The poor are constructed as deficient and in need of services that counteract the biological and psychosocial risk factors that limit [them from providing] care, stimulation and learning opportunities' that are understood to result in unequal development (RSA 2015:21). In this way, the policy locates social problems in the biological and psychosocial composition of the population affected by poverty. It emphasises solutions, such as passing on general information about parenting, rather than focusing on targeting the systemic drivers of basic and long-standing economic inequalities and discrimination that led to the impoverished circumstances that large sections of the population experience.
The policy is permeated by examples of responsibility for children's health and well-being being passed on to parents. This reflects the dominant practice described in other contexts (Vandenbroeck et al. 2010) and is visible in the major focus in the NIECDP on providing skills and information (especially for parents and through media campaigns) rather than the much needed material support. We will return to this topic later.

By drawing on a Western individualistic construction of risk and vulnerability, the policy also subjugates the indigenous African perspective that views 'being needed' and 'being in need' as inevitable and valuable features of life (Ebersöhn et al. 2014). Through the natural periods of vulnerability in one's personal life-cycle, or the shocks and stresses that impact families and communities, connectedness and reciprocity are key features of nurturing and caring responses. In contrast, the NIECDP does not refer explicitly to the strengths and resources of young children and their families or the role of social solidarity. Therefore, this kind of construction helps erase not only the complexity of worldviews but also the diversity of life experiences across each lifespan.

\section{Constructing the 'parent' and 'expert' binary}

The diagnostic report undertaken by the National Planning Commission that informed the vision of the National Development Plan (NDP) identified one of South Africa's nine key challenges as 'the standard of education for most black learners is of poor quality' (RSA 2011:3). The two proposals most closely linked to early childhood are a nutrition intervention for pregnant women and young children, and universal access to two years of ECD (RSA 2012). The plan constructs early childhood as an enabling milestone and links to it the need to 'increase the quality of education so that all children have at least two years of preschool education and all children in Grade 3 can read and write' (RSA 2012:3).

To achieve its goal, the NIECDP proposes a 'comprehensive package' of services (RSA 2015). Given that young children cannot wait for their rights to be progressively realised, especially in the critical period from conception to two years, the policy proposes an 'essential' package of services to promote their survival and development with immediate effect (Hall et al. 2017; RSA 2015). The 'essential package' will be implemented by 2024 as a stepping stone to the delivery of the 'comprehensive' package by 2030 (DBE, DSD \& DOH 2017). The essential package consists of maternal and child health services; nutrition support for pregnant women, mothers and children; support for primary caregivers, including parenting skills and psychosocial support; social services; and stimulation for early learning (Hall et al. 2017). The intention is to eventually make these programmes universally available through 'equitable access' (RSA 2015:48). While the intentions of the programme are commendable, the immediate effect is postponed to 2024 and the meaning of what will constitute 'equitable' remains undefined. 
The NIECDP also makes a clear distinction between the role of parents and technical expertise, as is evident in the quotation below (RSA 2015):

The inputs required for early childhood development include parental love, food, safety and stimulation. At the same time, there is a need for sufficient technical expertise to design and develop quality content for early learning, and to plan and manage large-scale services. Sufficient technical expertise is required to ensure that early childhood development in South Africa achieves the significant returns on investment achieved by a number of other countries. (p. 21)

What is provided by parents is defined here as love, food, safety and stimulation, all basic needs linked to healthy physical development, and includes stimulation for brain growth. So, the role of parents is limited to meeting the basic needs of children, while experts are constructed as those who are capable of providing learning experiences and services that ensure early childhood development. Parents and experts thus are constructed on a binary. The National Integrated ECD Policy defines a 'parent' as a (RSA 2015):

$[B]$ iological, foster or adoptive mother and/or father responsible for the care and protection of a young child, who is stable in the child's life and who loves the child and wants to protect the child. (p. 13)

This construction again circumscribes the capacity of the parent to ensure the child's basic needs. Moreover, as exemplified in the next quote from the essential package, the policy assumes little knowledge on behalf of parents to raise healthy and useful members of society, and they are therefore in need of 'factual information as well as the social support' ... 'to ensure the survival and development of their children to their full potential' (RSA 2015:58).

Parents and other caregivers are constructed as needing information and support to be able to 'understand and fulfil their role in children's early learning' (RSA 2015:27). Besides constructing parents as lacking competency, this perspective sidelines the possibility of citizens with an already rich understanding of their parental roles needing material resources rather than information. The policy proposes the development and implementation of systematised national communication campaigns that relay 'pertinent early childhood development messages' on topics such as nutrition and protection (RSA 2015). This top-down approach negates the complexity and material challenges many parents face in terms of feeding and protecting their children and distracts attention from the underlying causes of food insecurity and social conflict.

In summary, we can argue that despite its social transformation intentions, the 2015 ECD policy constitutes the primary problem as the need to prepare young children for schooling and prioritises the voices of early childhood 'experts' over beneficiaries, children and their families. By drawing uncritically on global discourses and normative notions of 'risk' and 'vulnerability', it constructs families living with poverty as deficient and in need of information campaigns and messages. The policy also suggests that 'communication aimed at parents should enable them to ... understand and demand quality early learning and development' (RSA 2015:45). This suggests that the authors of the information campaign must transfer their understanding of 'quality' and 'development' to beneficiaries who do not have their own constructions of childhood, well-being or the kind of society they want for themselves and their children. Parents must be told to 'demand' the prescribed services on offer without any opportunity to participate in designing the kind of services they want or explaining why they are not utilising available services.

\section{Data practice as population-based planning to solve the problem of poverty}

The current South African guiding framework for development, set out in the 2011 NDP and Vision 2030, ties in well with global discourses on the assumption that (RSA 2015):

[T] he loss of human capital is avoidable through the provision of timely and appropriate quality early childhood development services targeting the causes and consequences of the known risk factors. (p. 20, see note s36)

Laying down two fundamental objectives attached to measurable risk factors - to eliminate poverty and to reduce inequality (RSA 2011) - it addresses critical gaps 'to ensure the provision of a comprehensive, universally available and equitable early childhood development services' (RSA 2015:8). The notions of 'targeting', 'risk factors', 'critical gap', 'comprehensive' and 'universally available' together construct a policy field where data practices are needed and are the best tools to prepare decision-making about provision. Moreover, the plan is driven by an 'evidence-based' approach that seeks to measure success 'by the degree to which the lives and opportunities of the poorest South Africans are transformed in a sustainable manner' (Statistics South Africa 2017:6). This statement further contributes to constructing the need for measures, in this case, to assess delivery, and against which progress can be calculated. These notions and discourses create the need for and justify the top-down use of expert-driven data practices.

Based on available population-based data, the NIECDP identifies and prioritises 'the poorest 63.9 percent of children, since these comprise the most vulnerable children as well as the group that will benefit most from early childhood development services' (RSA 2015:68). The practice of targeting these children based on systematic data produces an affective structuration of society, locating vulnerability and hope in this objectified and uniform body of children. A different affect, that is, loss and despair, is also associated with this group of children: 'in the absence of appropriate and high quality early learning opportunities, earlier disparities in language and socio-emotional development determined by socio-economic status can become increasingly 
apparent' (RSA 2015:68). Constructing an affective structuration in society and mapping vulnerability against poverty, population-based planning is positioned as the most effective and equitable strategy for this assumed dire need (RSA 2015):

[T]o assess [the] scale and nature of the need for early childhood development services, and to plan for universal availability at a local level of sufficient early childhood development programmes in sufficiently close proximity to young children and their families, especially in under-serviced areas, to meet such demand. (p. 69)

Dahlberg (2016) warns that implementing standardised tools, which culminate in classifying children as "at risk" and/or "in need," may, if not scrutinised and contested, be counterproductive' by exacerbating marginalisation and limiting participation (Dahlberg 2016:128). On the one hand, dominant risk and vulnerability discourses in the NIECDP, and on the other hand objectification and uniformisation of a large section of the population through systematic data practice, produce knowledge from a hierarchical position. This knowledge marginalises the voices of beneficiaries, who are 'reduced to spectators' in this construction of the problem (Vandenbroeck et al. 2010). Moreover, by making poverty the primary indicator for vulnerability and linking vulnerability to the need for early childhood education, regulating the private life (such as their parenting practices within their homes) of those people, who are reckoned as poor according to data, becomes possible.

\section{Expanding regulative roles to technical experts}

The NIECDP refers to the 2001 Education White Paper 5 (2001) in acknowledging that an integrated approach requires the involvement of 'civil society organisations, the corporate sector, religious organisations, non-government organisations, parents and children' (RSA 2015:90). However, to enable targeting the NIECDP locates data practices within a centralised system where expertise is supposedly more available. The required data practices to do this work are described as follows (RSA 2015):

- Assess population-level needs for early childhood development services.

- Plan the provisioning of suitable early childhood development programmes and services to meet the identified needs (population-based planning).

- Develop and implement appropriate coverage targets and quality service standards and systems.

- Monitor compliance and provide support for ongoing quality improvement.

- Evaluate and report on progress. (p. 84)

To enable these processes, the government's first priority was to put in place the 'management structures and systems for population-based assessments' (RSA 2015:24). This is intended to aid in working out the number of services needed for different ages, places and 'developmental needs for the full range of early childhood development services at a national, provincial and municipal level' (RSA 2015:24).
This kind of data generation is what Kelly and Noonan (2017) term 'systematic' data practices. Data are collected based on large-scale population measures and trust is placed in these tools to show complex and extremely diverse economic, social and health conditions and needs. However, the data sets being used to determine the need and location of services cannot take account of complexity as they rely primarily on the macro aggregated socio-economic status of the community in which the service is situated. Besides, producing this type of data will require a gigantic machine of bureaucrats, professionals and 'measurement' experts to facilitate the envisioned systematic data practices and centralised planning, monitoring and reporting needed 'to strengthen, integrate and improve availability of and access' to these proposed ECD services (RSA 2015:48).

'Measurement experts' are given three major roles by the NIECDP: firstly, through using population data sets they determine the need for services; secondly, they assess the 'quality' of services by measuring learning outcomes; and thirdly, they monitor the impact of the system by using centrally predetermined indicators. All these roles rely on indicators established by early childhood 'experts' drawing on international discourses on quality, with no systematic participatory opportunities for beneficiaries to add to criteria. In summary, the NIECDP relies solely on centralised data based planning, implementation and monitoring and suggests that high-level collection and analysis of data is regarded as the most important planning tool. The focus of the initial implementation process is to build integrated national and provincial structures using systematic data practices for planning and monitoring. The NIECDP overlooks the responsibility of municipalities to implement early childhood services and the potential of the Integrated Development Plans for the participation of beneficiaries in local planning. The Toolkit of the Education and Training Unit (ETU) for Democracy and Development explains that 'Integrated Development Planning is an approach to planning that involves the entire municipality and its citizens in finding the best solutions to achieve good long-term development' (ETU 2018). While local government has failed to live up to the aims of decentralisation and participation set out in the 1997 Constitution of South Africa, there is growing renewed interest in it (Tshoose 2015). Past civil society experience and existing local government policy generate space for ongoing local dialogue that includes beneficiaries in planning early learning services.

\section{Reproducing coloniality through systematic data practices to measure learning outcomes}

The glossary of the NIECDP links quality to the measurement of the efficiency of interventions in the provision of ECEC: ' $(t)$ he quantity of interventions, services, programmes, training and systems linked with and achieving child outcomes' (RSA 2015:14). To explore this link further, it is important to reveal the colonial power hierarchies this document reproduces. Some observers hail the possibility that systematic data practices create for the comparison of 
service types and for the improvement of performance (Dawes et al. 2016). However, comparability is built on the selection of existing programmes deemed good quality and worthy of replicating. Thus, 'five well-capacitated non-profit organizations were invited to submit proposals for ECD interventions that responded to key identified issues' (Biersteker \& Dawes 2019:94). Consequently, the quality of services in the future will not only be compared to interventions selected and supported by well-resourced training organisations, but also on a historical measure of quality, and thus side-lining the knowledge and changing experiences of communities. This accommodates scaling up existing kinds of services, leaving little opportunity to generate innovation.

To understand the effect of this systematic data practice requires attention to historical legacies. Apartheid has generated the intractable problem of spatial inequality that has resulted in continued unequal access to services, including schooling (Vally, Motala \& Ramadiro 2010). Goldberg (2009) argues that post 1994, racial apartheid has transformed into a more generic and so supposedly less pernicious class apartheid. He identifies neoliberalisation as a contributing factor, since segregation based on racial classification has been displaced by separation based on access to material resources as we have described earlier. South African citizens now have the opportunity to make choices that can only be made (Goldberg 2009):

[W]ithin the limits of one's means and networks, one's inheritance and education, one's class and gender, all of which are racially marked if much less deeply and directly determined than under apartheid. (p. 528)

The way government constitutes the problem, constrains Biersteker and Dawes in the development of measurement tools and the selection of data practices. This produces unintended consequences. Biersteker and Dawes (2019:93) acknowledge that despite the intention to design programmes using local knowledges, 'very little space is afforded to these when it comes to measurement and evaluation'. In developing the learning outcomes and their measurement, they sought to determine the extent to which indigenous rather than globalised modern practices might influence the skills commonly assessed in development tests. In their argument for using globalised modern practices, they claim that rural children today in traditional settings are neither as exposed to indigenous practices nor as insulated from modern practices as they were 20 years ago. They base this claim on data about increased urbanisation, access to television, mobile telephones and electricity. Consequently, they calculate that those young children who are primarily exposed to indigenous early childhood practices are 'probably restricted to more remote rural areas' (Biersteker \& Dawes 2019:93). With their specific data use, they circumscribe and erase from consideration an assumedly small community not really worthy of consideration in a national policy.

We read this tactic as the presence of coloniality that subjugates valuable perspectives, such as 'connection and relatedness' in the African tradition of 'ubuntu' (Green 2013; Mji 2012). Their conclusion disregards the need to preserve indigenous understandings that continue even in urban contexts. In adapting the globally designed test items to the local context, they focus on differences in language use and the difference in the nature and prevalence of objects in varying areas. For example, they replace the word 'squirrel' in test items with 'mouse', which is more universally present in South Africa. This kind of adaptation of test items borrowed from developmental psychology consequently reinforces the dominant and normalised constructions of childhood that further favours 'white', male, middle class norms and values (Burman 2007). Burman (2007) reminds us that we need to consider the emergence of this kind of 'mental measurement, classification of abilities and establishment of norms' as historically located during the industrial revolution with the purpose of regulating 'those populations deemed a social threat to the prevailing order' (2007:13-14).

A genuinely integrated approach that accommodates multiple visions of childhood and society would generate complexity that is perhaps more difficult to manage with systematic data practices. In the face of this complexity, Biersteker and Dawes (2019) do not take into consideration community-based ECD services. This type of service does 'not readily lend itself to requirements of formal evaluation' as these services frequently respond to community priorities and a complex range of interacting factors (Biersteker \& Dawes 2019:94). They also acknowledge that 'randomization is extremely tricky in many situations' in the context of diversity (Biersteker \& Dawes 2019). By including the early childhood practitioners that they have trained as assessors in the piloting of standardised tests, they assume that they can account for the multiplicity of viewpoints. However, they do not consider that although assessors might live in marginalised communities, they might not represent the full range of local perspectives. Unlike the majority of the targeted population of ECD services, trained practitioners will inevitably already have achieved some success within the education system in which Western knowledge dominates, subjugating indigenous knowledges.

Systematic data practices do not easily accommodate the complexity of integrated approaches that respond to local contexts and constantly changing priorities. Kelly and Noonan (2017) suggest 'edifying practices' to grapple with complex conditions. In 'edifying data practices', data are revealed through 'patient engagement with' local conditions in non-judgmental and attentive dialogue with local stakeholders, as opposed to standard systematic data practices that erase local differences and act as an arbiter between competing claims to truth (Kelly \& Noonan 2017:885). 'Edifying practices' assume a dialogical approach generating mutual exploration and learning through conversation, while in standard evaluation approaches, authority is produced through a hierarchical position with a tendency towards reprimand and risk aversion. In 'edifying data practices', 'authority is produced through demonstrated situated expertise' with 'tendencies towards openness and 
experimentation' (Kelly \& Noonan 2017:885). Conversation generates receptiveness through curious and sympathetic dispositions to compel the search for other perspectives. The currently adapted learning outcomes in South Africa unfortunately allow little scope for innovation to emerge outside of the predetermined indicators.

Despite the acclaim for the learning outcomes in South Africa, recent global literature, on this kind of data practice, raises several red flags. The learning outcomes are designed for comparison so that 'data can flow and travel well', creating spaces for international comparison instead of a detailed portrayal of local conditions and achievements (Piattoeva 2015:14). By tracking the power of numbers in the data generated in national examinations, Piattoeva raises important considerations. She illustrates how these kinds of numbers can be used for different government purposes and at the same time 'preclude criticism of their political effects' (Piattoeva 2015:14). These political effects are varied; for example, Bradbury draws on the experience of testing fiveyear-old children since 2003 in England to warn that the production of numerical data in early childhood education creates a 'high stakes situation' that can lead to more time 'teaching the test' than supporting the learning and wellbeing of young children (Bradbury 2014:336). Roberts-Holmes and Bradbury (2016:600) draw on the testing of children aged five years old in England to show how the 'surveillance and performative culture of accountability both affirms, legitimates and seduces through discourses of quality while increasingly regulating and governing the early years'. Millei and Gallagher (2017) show the complex entanglements that data practices produce and the resulting ambivalent positions in which professionals find themselves. They reveal the ethical dilemmas, practical and material consequences, as well as the political possibilities for resistance and advocacy that data practices bring forward. Millei and Gallagher (forthcoming) also illustrate how data practices actually can work against the stated initiative of universal access and create new forms of inequalities instead of overcoming those.

\section{The 'government of poverty'}

The withering away of ANC policy commitments and principles is evident across many policy sectors. It is also visible in the dominant government strategies for addressing poverty that some argue is a strategy to merely manage the consequences of rising unemployment and inequality (Du Toit 2017; Hickey 2014; Seekings 2014), rather than as a strategy for meaningful social change intended in the Freedom Charter (ANC 1955). Du Toit (2017) calls this policy strategy the 'government of poverty'. In this article, we have demonstrated how through systematic data practices the NIECDP 'governs poverty' by objectifying and constituting a large section of the population as vulnerable, thus needing intervention into their lives. Part of this form of governance is to place the power to make decisions about resources in the hands of measurement experts rather than engaging the service providers and beneficiaries in ongoing reflection and action. While acknowledging that social grants and other pro-poor government policies have alleviated some suffering for many families in South Africa, Du Toit (2017) points to:

$[D]$ isplacement of a political practice of popular mobilization and social transformation by a new technocratic rationality of government that seeks to construct poor populations (and poverty as such) as objects of scientific knowledge, understanding and technical intervention. (p. 2)

$\mathrm{Du}$ Toit explains that the use of mostly quantitative and usually fairly positivistic discourses promoting 'evidencebased policymaking' has institutionalised the 'power and voice of a distinct cadre of technical experts and professional bureaucrats', who generate the 'knowledge' used to make decisions about resource allocations to vulnerable and marginalised communities (Du Toit 2017:2).

This notion of 'government of poverty' used by Du Toit to argue that evidence-based policymaking discourses undermine local decision-making in marginalised communities also holds true for the NIECDP, which in a similar manner prioritises and adapts the globalised neoliberal discourses and practices of measurement experts to the constructed problems of the government. However, in Foucault's (1991) terms, discursive practice is always in flux and power is not fixed; moreover, where there is power there is resistance. Consequently, change is possible with the capacity to recognise and question norms and constraints. Kelly and Noonan suggest reconsidering 'conceptions of data as a given "thing" that unproblematically reflects an underlying reality and to focus instead on how data are made and what this making does' (Kelly \& Noonan 2017:879). For example, this kind of thinking raises the possibility of re-examining the kind of individuals, groups and needs that are identified and constituted through different kinds of data practices. They also highlight the importance of studying the relations between data, knowing and managing. They encourage unpacking 'practices of datafication' and relating them to the 'broader practices of organizational knowing in which they are typically embedded' (Kelly \& Noonan 2017:876). In particular, they call attention to finding or creating data practices that can accommodate uncertainty and contingency and keep the conversation open through dialogue that attends to power relations and diversity.

In this article, we show the ways in which systematic data practices in South African early childhood policy brush over complex conditions, legitimate their own use and silence less-dominant knowledges of local communities. If governments are truly concerned about inequality and the future of their countries, instead of governing poverty, they could engage in dialogue with families and communities about the kind of society they want for themselves and their children and find out what help they need to build that kind of society. This article takes a first step to open spaces for this type of engagement by inviting the readers to think about power relations and data practices prevalent in and proposed by the NIECDP to better understand: who benefits, who speaks and who is silenced. 


\section{Acknowledgements}

The first author would like to thank the University of Jyväskylä, Department of Education, for the doctoral thesis postgraduate education grant.

\section{Competing interests}

The authors declare that they have no financial or personal relationships that may have inappropriately influenced them in writing this article.

\section{Authors' contributions}

The first author (N.R.) conceptualised the article, undertook all the analysis, reviewed the literature, wrote the article and integrated comments as part of an article-based doctoral study. The second (Z.M.) and third (M.A.) authors are both supervisors of the first author. The second author gave detailed written comments on the content and structure. The third author gave general oral feedback and support.

\section{Ethical considerations}

This study did not require ethical clearance.

\section{Funding information}

The first author received a scholarship from the University of Jyväskylä during part of the period of work on the article. This article was published with financial support from the Department of Higher Education and Training, South Africa, through a grant from the Centre of Education Practice Research at the University of Johannesburg.

\section{Data availability statement}

Data sharing is not applicable to this article as no new data were created or analysed in this study.

\section{Disclaimer}

The views expressed in this article are the authors' own and not the official position of their institutions or funders.

\section{References}

ANC, 1955, The Freedom Charter, viewed 10 March 2019, from African National Congress website: https://www.anc1912.org.za/freedom-charter.

Bacchi, C., 2000, 'Policy as discourse: What does it mean? Where does it get us?', Discourse: Studies in the Cultural Politics of Education 21, 45-57. https://doi. org/10.1080/01596300050005493

Biersteker, L., 2018, 'Early childhood education and social transformation in South Africa: The emergence of early childhood education as a priority in South Africa' in J.L. Roopnarine, J.E. Johnson, S.F. Quinn \& M.M. Patte (eds.), Handbook of international perspectives on early childhood education, pp. 296-310, Routledge, New York and Abingdon.

Biersteker, L. \& Dawes, A., 2019, 'South Africa: Measuring up - The Sobambisana evaluation', in P.H.E. Kjørholt At (ed.), Early childhood and development work, pp. 91-112, Palgrave Macmillan, London.

Bradbury, A., 2014, 'Early childhood assessment: Observation, teacher "knowledge" and the production of attainment data in early years settings AU - Bradbury, Alice', Comparative Education 50, 322-339. https://doi.org/10.1080/03050068.2 014.921371

Britto, P.R., Lye, S.J., Proulx, K., Yousafzai, A.K., Matthews, S.G., Vaivada, T. et al., 2017 'Nurturing care: Promoting early childhood development', The Lancet 389, 91-102. https://doi.org/10.1016/S0140-6736(16)31390-3
Britto, P.R., Singh, M., Dua, T., Kaur, R. \& Yousafzai, A.K., 2018, 'What implementation evidence matters: Scaling-up nurturing interventions that promote early childhood development', Annals of the New York Academy of Sciences 1419, 5-16. https://doi.org/10.1111/nyas.13720

Burman, E., 2007, Deconstructing developmental psychology, 2nd edn., Taylor and Francis, Hoboken, NJ.

Campbell-Barr, V., Lavelle, M. \& Wickett, K., 2012, 'Exploring alternative approaches to child outcome assessments in children's centres', Early Child Development and Care 182, 859-874. https://doi.org/10.1080/03004430.2011.590937

Cannella, G.S., Pèrez, M.S. \& Lee, I.F., 2016, Critical examinations of quality in early education and care: Regulation, disqualification, and erasure, Peter Lang, New York.

Centre on the Developing Child, 2007, A science-based framework for early childhood Policy, Centre on the Developing Child, Harvard University, Cambridge.

Christie, P., 2010, 'The complexity of human rights in global times: The case of the right to education in South Africa', International Journal of Educational Development 30, 3-11. https://doi.org/10.1016/j.ijedudev.2009.06.006

Dahlberg, G., 2016, 'An ethico-aesthetic paradigm as an alternative discourse to the quality assurance discourse', Contemporary Issues in Early Childhood 17, 124-133. https://doi.org/10.1177/1463949115627910

Dahlberg, G. \& Moss, P., 2005, Ethics and politics in early childhood education Routledge Falmer, Abington.

Dahlberg, G., Moss, P. \& Pence, A., 1999, Beyond quality in early childhood education and care, Falmer Press, London.

Dawes, A., Biersteker, L., Girdwood, E., Snelling, M. \& Tredoux, C., 2016, The development and age validation of the early learning outcome measure (ELOM) Innovation Edge briefing document, viewed 10 December 2016, from http:// Innovation Edge briefing document, viewed 10 December 2016, from
elom.org.za/wp-content/uploads/2017/07/ELOM-Briefing-Document.pdf.

DBE, DSD \& DOH, 2017, Briefing on early childhood development - Joint Portfolio Committee, viewed 31 October 2017, from https://slideplayer.com/slide/ Committee,

DGM Moderator, 2016, Early learning gets a boost - ELOM and SmartStart, viewed 19 September 2016, from http://dgmt.co.za/?p=7929.

DoE, 1996, Interim policy for early childhood development. Department of Education, South African Government Printers, Pretoria.

DoE, DOH \& DSD, 2005, National integrated plan (NIP) 2005-2010, viewed 11 August 2007, from http://www.unicef.org/southafrica/SAF_resources_nip.pdf.

DSD, 2005, Children's act 38, Government Printers, Pretoria, viewed 10 August 2008 from http://www.justice.gov.za/legislation/acts/2005-038\%20childrensact.pdf.

Du Toit, A., 2012, Making sense of 'evidence': Notes on the discursive politics of research and pro-poor policy making, UWC, PLAAS, Bellville.

Du Toit, A., 2017, Hyper-political anti-politics. Open democracy: Free thinking for the world, viewed 04 November 2017, from https://www.opendemocracy.net/ andries-du-toit/hyper-political-anti-politics.

Ebersöhn, L., Sefotho, M., Mampane, R., Loots, T., Omidire, F., Sherman, V. et al., 2014, Imbeleko Report: Cultivating resourcefulness, not dependency, viewed 30 January 2019, from https://bettercarenetwork.org/sites/default/files/Imbeleko $\% 20$ Report $\% 20-\% 20$ Cultivating $\% 20$ Resourcefulness, $\% 20$ Not $\% 20$ Dependency.pdf.

ELRU, 1994, A proposed model of ECD service provision, with the emphasis on the reception year (called the 'alternative approach'), Early Learning Resources Unit (ELRU), Cape Town.

ETU, 2018, Integrated development planning for local government, viewed 06 February 2018, from http://www.etu.org.za/toolbox/docs/localgov/webidp.html.

Foucault, M., 1991, 'Politics and the study of discourse', in G. Burchell \& D.M. Miller (eds.), The Foucault effect: Studies in governability, pp. 53-72, University of Chicago Press, Chicago, IL.

Goldberg, D.T., 2009, 'A political theology of race: Articulating racial Southafricanization', Cultural Studies 23, 513-537. https://doi.org/10.1080/09502380902950955

Green, L., 2013, Contested ecologies: Dialogues in the south on nature and knowledge, L. Green (ed.), HSRC Press, Pretoria, viewed 20 March 2017, from www.hsrcpress. ac.za.

Grek, S. \& Ozga, J., 2010, 'Re-inventing public education: The new role of knowledge in education policy making', Public Policy and Administration 25, 271-288. https://doi.org/10.1177/0952076709356870

Hall, K., Sambu, W.L.B., Giese, S. \& Almeleh, C., 2017, South African early childhood review 2017, Children's Institute, University of Cape Town and Ilifa Labantwana, Cape Town.

Hickey, S., 2014, 'Relocating social protection within a radical project of social justice', The European Journal of Development Research 26, 322-337. https://doi. org/10.1057/ejdr.2014.9

Kelly, S. \& Noonan, C., 2017, 'The doing of datafication (and what this doing does): Practices of edification and the enactment of new forms of sociality in the Indian public health service', Journal of the Association for Information Systems 18, 872-899. https://doi.org/10.17705/1jais.00477

Kendall, G. \& Wickham, G., 1999, Using Foucault's methods, Sage, London, viewed 16 February 2019, from http://methods.sagepub.com/book/using-foucaultsmethods.

Meintjes, H. \& Giese, S., 2006, 'Spinning the epidemic the making of mythologies of orphanhood in the context of AIDS', Childhood 13, 407-430. https://doi org/10.1177/0907568206066359

Mignolo, W.D., 2007, 'Delinking: The rhetoric of modernity, the logic of coloniality and the grammar of de-coloniality', Cultural Studies 21, 449-514. https://doi.org/ 10.1080/09502380601162647 
Millei, Z. \& Gallagher, J., 2017, 'Ad-hoc numbers forming provision and policy: Round and round of universal access in an Australian preschool', Early Child Development and Care 187, 1528-1542. https://doi.org/10.1080/03004430.2017. 1289926

Millei, Z. \& Gallagher, J., (in-press), 'The paradox of universal access: Alleviating or perpetuating inequity for children in NSW Australia', in M. Alasuutari, childhood education: Does equal access matter?, Edward Elgar Publishing, Cheltenham, United Kingdom.

Mji, G., 2012, 'The health knowledge utilised by rural older Xhosa women in the management of health problems in their home situation, with special focus on indigenous knowledge', PhD unpublished dissertation presented for the degree of Doctor in Philosophy in Family Medicine, Stellenbosch University.

Morabito, C., Vandenbroeck, M. \& Roose, R., 2013, 'The greatest of equalisers': A critical review of international organisations' views on early childhood care and education', Journal of Social Policy 42, 451-467. https://doi.org/10.1017/ S0047279413000214

National Planning Commission, 2012, National development plan 2030: Our futuremake it work, Presidency of South Africa, Pretoria.

Penn, H., 2010, 'Shaping the future: How human capital arguments about investmen in early childhood are being (mis)used in poor countries', in N. Yelland (ed.) Contemporary perspectives on early childhood education, pp. 49-65, Open University Press, Maidenhead.

Piattoeva, N., 2015, 'Elastic numbers: National examinations data as a technology of government AU - Piattoeva, Nelli', Journal of Education Policy 30, 316-334. https://doi.org/10.1080/02680939.2014.937830

Porteus, K., 2004, 'The state of play in early childhood development', in L. Chisholm (ed.), Changing class: Education and social change in post apartheid South Africa, pp. 339-365, Human Sciences Research Council, Cape Town.

Richter, L., Biersteker, L., Burns, J., Desmond, C., Feza, N., Harrison, D. et al., 2012 Diagnostic review of early childhood development, viewed 11 January 2014,
from https://www.dpme.gov.za/keyfocusareas/evaluationsSite/Evaluations/ Diagnostic\%20Review\%20of\%20Early\%20Childhood\%20Development.pdf.

Roberts-Holmes, G., 2015, "The "datafication" of early years pedagogy: "If the teaching is good, the data should be good and if there's bad teaching, there is bad data"', Journal of Education Policy 30, 302-315. https://doi.org/10.1080/0268093 9.2014 .924561

Roberts-Holmes, G. \& Bradbury, A., 2016, 'Governance, accountability and the datafication of early years education in England', British Educational Research Journal 42(4), 600-613. https://doi.org/10.1002/berj.3221

Rorty, R., 1979, Philosophy and the mirror of nature, Princeton University Press, Princeton, NJ.

RSA, 2011, National development plan: Vision for 2030, National Planning Commission (ed.), South African Government, Republic of South Africa, viewed 16 July 2014 from http://www.gov.za/issues/national-development-plan-2030.

RSA, 2012, National development plan 2030: Our future - Make it work, South African Government, viewed 16 July 2014, from http://www.gov.za/issues/nationaldevelopment-plan/.

RSA, 2015, National integrated early childhood development policy, Government Printers, Pretoria.
Rudolph, N., 2017, 'Hierarchies of knowledge, incommensurabilities and silences in South African ECD policy: Whose knowledge counts?', Journal of Pedagogy/ Pedagogický Casopis 8, 77-98. https://doi.org/10.1515/jped-2017-0004

Rudolph, N., Monson, J., Collett, K. \& Sonn, B., 2008, Champions for children handbook: How to build a caring school community (pilot version), Children's Institute, University of Cape Town, Cape Town.

Santos, B.D.S., 2007, 'Beyond abyssal thinking: From global lines to ecologies of knowledges*', Review of African Political Economy 30, 1-33, viewed 22 June 2016 from www.eurozine.com

Seekings, J., 2014, 'The social and political implications of demographic change in post-apartheid South Africa', The ANNALS of the American Academy of Political and Social Science 652, 70-86. https://doi.org/10.1177/00027 16213508265

Shore, C. \& Wright, S., 2011, 'Introduction. Conceptualising policy: Technologies of governance and the politics of visibility', in C. Shore, S. Wright \& D. Pero (eds.) Policy worlds: Anthropology and the analysis of contemporary power, pp. 1-25, Berghahn Books. New York.

Snelling, M., Dawes, A., Biersteker, L., Girdwood, E. \& Tredoux, C., 2019, 'The development of a South African early learning outcomes measure (ELOM): A South African instrument for measuring early learning program outcomes' Child: Care, Health and Development 45(2), 257-270. https://doi.org/10.1111/ cch.12641

Soudien, C., 2004, 'Constituting the class': An analysis of the process of "integration" in South African schools', in L. Chisholm (ed.), Changing class: Education and social

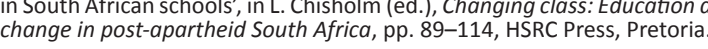

Spreen, C.A., Vally, S. \& Thapilyal, N., 2012, 'The limits of post-apartheid education policy: Knowledge, power and community mobilization for education rights in South Africa', World Studies in Education 13,51-65. https://doi.org/10.7459/ wse/13.2.05

Statistics South Africa, 2017, Poverty trends in South Africa: An examination of absolute poverty between 2006 and 2015, Statistics South Africa, Pretoria.

Swart, T., 1996, 'Helping parents build on natural learning', in Recovery: Research and cooperation on violence education and rehabilitation of young people, vol. 1 , pp. 10-26, Recovery, Durban.

Tshoose, C.I., 2015, 'Dynamics of public participation in local government: A South African perspective', African Journal of Public Affairs 8, 13-29.

UNICEF, 2012, Inequities in early childhood development: What the data say evidence from the multiple indicator Cluster surveys, United Nations Children's Fund, New York.

Unterhalter, E., 2009, 'Social justice, development theory and the question of education', in R. Cowen \& A.M. Kazamias (eds.), International handbook of comparative education, pp. 781-799, Springer and Science + Business Media B.V. London.

Vally, S. Motala, E. \& Ramadiro, B., 2010 'Education rights, education policies, and inequality in South Africa', in S. Macrine, P. Mclaren \& D. Hill (eds.), Revolutionizing pedagogy: Education for social justice within and beyond global neo-liberalism, pedagogy: Education for social justice within
pp. 41-63, Palgrave Macmillan, New York.

Vandenbroeck, M. Coussée, F. \& Bradt, L, 2010 'The social and political construction of early childhood education', British Journal of Educational Studies 58, 139-153. https://doi.org/10.1080/00071001003752237 